\title{
FUTURE MEDICAL DOCTORS ARE READY TO PRESCRIBE ANTIMICROBIALS SAFELY AND RATIONALLY
}

Medical microbiologist and immunologist wrote in 1956 overall, antimicrobials in medical therapy are highly satisfactory. Most of "bacterial infections can be cured simply, effectively, and cheaply. The mortality and morbidity from bacterial diseases have fallen so low that they are no longer among the important unsolved problems of medicine. These accomplishments are widely known and appreciated" [1]. The Nobel laureate Dr. Frank Macfarlane Burnet wrote the following in 1962 "one can think of the middle of the 20th century as the end of one of the most important social revolutions in history, the virtual elimination of the infectious diseases as a significant factor in social life" [2]. The United States Surgeon General, William H. Stewart (1965-1969) uttered that "it is time to close the book on infectious diseases, and declare the war against pestilence won" [3]. Thereafter, the outstanding achievement of antimicrobial drugs generated a misapprehension in the late 1960s and early 1970s that infectious ailments had been defeated. Nevertheless, in 40-50 years' time, currently, infectious diseases remain the third-leading cause of death in the USA [4] and the second-leading cause of death of our planet [5]. Henceforth concerned microbiologist, infectious diseases specialists, and enlighten people raised their voice in their scientific writings have continually stated that above-mentioned quotes were not on the basis of science [6-11]. The everlasting flare-up of antibiotic-resistant infections continues to pestilence global health care $[12,13]$. Antimicrobial resistance affects both developing and developed countries. Recent global estimates in 2015 reveal 480,000 new cases of multidrug-resistant tuberculosis (MDR-TB), additional 100000 people with rifampicin-resistant TB who were also newly eligible for MDR-TB treatment, and extensively drugresistant TB present in 117 countries and at least one case was detected by $2015[14,15]$.

The treatment of microbial infections in prehistoric Egypt, Greece, China, and some other places of the planet is well documented [16]. The current epoch of antibiotics on track with the discovery of penicillin by Sir Alexander Fleming in 1928. Since then, antibiotics contributed a lot for mankind and saved millions of lives. The situation and conquering over microbial diseases have been totally changed in past few decades. Overuse, misuse, and unnecessary of antimicrobials have been blamed principally for the growth and expansion of microbial resistance [17-23]. The Guardian made a headline news that "doctors write 10 million needless antibiotic prescriptions a year" [24]. Moreover, multiple studies reported from all over the planet that medical students are not adequately prepared to prescribe antimicrobials appropriately [25-31]. Prescribing medicines is the most common clinical intervention for any medical doctor throughout their working life to recuperate the health of their patients [32]. Moreover, prescribing is a multifaceted, thought-provoking, and progressively onerous job that necessitates a comprehensive knowledge of medicine and diseases combined with an empathetic attitude of care and integrity toward the patient and the society $[33,34]$. The prescribing process includes essential four steps: (i) Precise diagnosis; (ii) evaluating the benefit to harm; (iii) selecting the right drug, dose, and necessary dialog with the patient about the anticipated treatment options; and (iv) probable beneficial and adverse effects [35]. There has a long history of clinical pharmacology in promoting rational prescribing but students highly dissatisfied regarding teaching therapeutics and their preparedness toward prescribing. Students have reported that they were not provided enough time in the development of real-world therapeutics [35,36]. Another study conducted in 30 of the 32 UK medical schools reported that clinical pharmacology and therapeutics teaching in these medical schools is quite disparate and the majority of the schools possess any assessment program to evaluate students prescribing skill. Moreover, whether teaching programs were directed for the development real-world prescribing skill [37]. The theoretical, clinical pharmacology and rational therapeutics teaching transfer knowledge to undergraduate medical students; however, students failed retained this theoretical knowledge when they graduated. Hence, young medical doctors are adequately prepared to face the everyday life to prescribe the safe and rational use of medicine [38]. The principal goal of clinical pharmacology and therapeutics is "to improve the care of patients by promoting the safe and effective use of medicines and to evaluate and introduce new therapies" [39]. Therefore, the answer remains in improving clinical pharmacology teaching and learning in undergraduate curriculum $[40,41]$ with necessary assessment program regarding prescribing skill [40] need to incorporate with the hope situation will improve to provide better health care for common people of this planet.

\section{MAINUL HAQUE*}

Faculty of Medicine and Defence Health, National Defence University of Malaysia, Kem Sungai Besi, 57000 Kuala Lumpur, Malaysia. Email: runurono@gmail.com

Received: 10 August 2017, Revised and Accepted: 15 September 2017

\section{REFERENCES}

1. Jawetz E. Antimicrobial chemotherapy. Annu Rev Microbiol 1956;10:85-114

2. Burnet M. Natural History of Infectious Disease. Cambridge, UK: Cambridge University Press; 1962.

3. Spellberg B, Taylor-Blake B. On the exoneration of Dr. William H. Stewart: Debunking an urban legend. Infect Dis Poverty 2013;2(1):3.

4. Pinner RW, Teutsch SM, Simonsen L, Klug LA, Graber JM, Clarke MJ, et al. Trends in infectious diseases mortality in the United States. JAMA 1996;275(3):189-93.

5. World Health Organization (WHO). Deaths by Cause, Sex and Mortality Stratum in WHO Regions, Estimates for 2001, World Health Report-2002. Geneva, Switzerland: World Health Organization; 2002. Available from: http:/www.who.int/whr/2002/en/whr02_en.pdf?ua=1. [Last accessed on 2017 Aug 10].

6. Spellberg B. Dr. William H. Stewart: Mistaken or maligned? Clin Infect Dis 2008;47(2):294

7. Spellberg B, Guidos R, Gilbert D, Bradley J, Boucher HW, Scheld WM, et al. The epidemic of antibiotic-resistant infections: A call to action for the medical community from the Infectious Diseases Society of America. Clin Infect Dis 2008;46(2):155-64.

8. Spellberg B, Powers JH, Brass EP, Miller LG, Edwards JE Jr. Trends in antimicrobial drug development: Implications for the future. Clin Infect Dis 2004;38(9):1279-86.

9. Fauci AS. Infectious diseases: Considerations for the $21^{\text {st }}$ century. Clin Infect Dis 2001;32(5):675-85.

10. Petersdorf RG. The doctors' dilemma. N Engl J Med 1978;299(12):628-34.

11. Petersdorf RG. Whither infectious diseases? Memories, manpower, and money. J Infect Dis 1986;153(2):189-95.

12. Palumbi SR. Humans as the world's greatest evolutionary force. Science 2001;293(5536):1786-90.

13. Alanis AJ. Resistance to antibiotics: Are we in the post-antibiotic era? Arch Med Res 2005;36(6):697-705

14. World Health Organization (WHO). Multidrug-Resistant Tuberculosis (MDR-TB). WHO; 2016. Available from: http://www.who.int/tb/ challenges $/ \mathrm{mdr} / \mathrm{mdr}$ tb factsheet.pdf. [Last accessed on 2017 Aug 5].

15. World Health Organization (WHO). Tuberculosis (TB). Drug-resistant TB: XDR-TB FAQ, Extensively Drug-Resistant Tuberculosis (TB). 
World Health Organization; 2017. Available from: http:/www.who. int/tb/areas-of-work/drug-resistant-tb/xdr-tb-faq/en. [Last accessed on 2017 Aug 5].

16. Sengupta S, Chattopadhyay MK, Grossart HP. The multifaceted roles of antibiotics and antibiotic resistance in nature. Front Microbiol $2013 ; 4: 47$

17. Kelland K. EU doctors turn to last-ditch antibiotics as resistance grows. Chicago Tribune; 2012. Available from: http://www.articles. chicagotribune.com/2012-11-15/business/sns-rt-europe-antibiotics superbugs15e8mf701-20121115_1_antibiotic-resistance-superbugsbloodstream-infections. [Last accessed on 2017 Aug 5]

18. Foote C. Overuse of antibiotics-doctors, not patients, to blame? BMC Ser Blog 2013. Available from: https://www.blogs.biomedcentral.com/ bmcseriesblog/2013/05/31/overuse-of-antibiotics-doctors-not-patientsto-blame. [Last accessed on 2017 Aug 5]

19. Ventola CL. The antibiotic resistance crisis: Part 1: Causes and threats. P T 2015;40(4):277-83

20. The Economist Resistance to antibiotics, The Spread of Superbugs, What can be Done About the Rising Risk of Antibiotic Resistance? 2011. Available from: http://www.economist.com/node/18483671. [Last accessed on 2017 Aug 5].

21. McCartney M. Margaret McCartney: Blaming doctors won't reduce antibiotic overuse. BMJ 2015;351:h4697.

22. Harrison JW, Svec TA. The beginning of the end of the antibiotic era? Part I. The problem: Abuse of the "miracle drugs". Quintessence Int 1998;29(3):151-62.

23. Harrison JW, Svec TA. The beginning of the end of the antibiotic era? Part II. Proposed solutions to antibiotic abuse. Quintessence Int 1998;29(4):223-9.

24. Meikle J. Doctors Write $10 \mathrm{~m}$ Needless Antibiotic Prescriptions a Year, Says NICE. The Guardian; 2015. Available from: https://www. theguardian.com/society/2015/aug/18/soft-touch-doctors-write-10mneedless-prescriptions-a-year-says-nice. [Last accessed on 2017 Aug 6].

25. Abbo LM, Cosgrove SE, Pottinger PS, Pereyra M, SinkowitzCochran R, Srinivasan A, et al. Medical students' perceptions and knowledge about antimicrobial stewardship: How are we educating our future prescribers? Clin Infect Dis 2013;57(5):631-8.

26. Khan AK, Banu G,Reshma KK. Antibiotic resistance and usage-a survey on the knowledge, attitude, perceptions and practices among the medical students of a Southern Indian Teaching Hospital. J Clin Diagn Res 2013;7(8):1613-6.

27. Dyar OJ, Howard P, Nathwani D, Pulcini C, ESGAP (the ESCMID [European Society of Clinical Microbiology, Infectious Diseases] Study Group for Antibiotic Policies). Knowledge, attitudes, and beliefs of French medical students about antibiotic prescribing and resistance. Med Mal Infect 2013;43(10):423-30.
28. Wasserman S, Potgieter S, Shoul E, Constant D, Stewart A, Mendelson M, et al. South African medical students' perceptions and knowledge about antibiotic resistance and appropriate prescribing: Are we providing adequate training to future prescribers? S Afr Med J 2017;107(5):405-10.

29. Chambers D. Trainee Doctors Not Adequately Prepared To Prescribe Antibiotics, Study finds. Business Day; 2017. Available from: https:// www.businesslive.co.za/bd/national/health/2017-05-01-traineedoctors-not-adequately-prepared-to-prescribe-antibiotics-study-finds. [Last accessed on 2017 Aug 5]

30. Ferdoush J, Parveen K, Ata M, Reza FH, Rahman MS. Knowledge, perception and preparedness of future prescribers about antimicrobial stewardship. Bangladesh J Pharmacol 2016;11(4):928-34.

31. Brinkman DJ, Tichelaar J, Schutte T, Benemei S, Böttiger Y, Chamontin B et al. Essential competencies in prescribing: A first european cross-sectional study among 895 final-year medical students. Clin Pharmacol Ther 2017;101(2):281-9.

32. Mucklow J, Bollington L, Maxwell S. Assessing prescribing competence. Br J Clin Pharmacol 2012;74(4):632-9

33. Khan AK, Rashed MR, Muneersha TK, Rahiman OM. Assessment of the prescribing knowledge, attitude and skills of medical students and interns in a large teaching hospital of Southern India. Biomed Pharmacol J 2013;6(1):63-9.

34. Ross S, Loke YK. Do educational interventions improve prescribing by medical students and junior doctors? A systematic review. Br J Clin Pharmacol 2009;67(6):662-70.

35. Aronson JK. A prescription for better prescribing. Br J Clin Pharmacol 2006;61(5):487-91.

36. Ellis A. Prescribing rights: Are medical students properly prepared for them? Br Med J 2002;324:1591.

37. O'Shaughnessy L, Haq I, Maxwell S, Llewelyn M. Teaching of clinical pharmacology and therapeutics in UK medical schools: Current status in 2009. Br J Clin Pharmacol 2010;70(1):143-8

38. Desai MK, Panchal JR, Shah S, Iyer G. Evaluation of impact of teaching clinical pharmacology and rational therapeutics to medical undergraduates and interns. Int J Appl Basic Med Res 2016;6(3):205-10.

39. Royal College of Physicians. Clinical Pharmacology and Therapeutics in a Changing World. Report of a Working Party. London: RCP; 1999. Available from: https://www.cdn.shopify.com/s/files/1/0924/4392/ files/clin_pharm_1999web.pdf. [Last accessed on 2017 Aug 6].

40. Maxwell SR. An agenda for UK clinical pharmacology. How should teaching of undergraduates in clinical pharmacology and therapeutics be delivered and assessed? Br J Clin Pharmcol 2016;73(6):893-9.

41. Upadhyaya P, Seth V, Sharma M, Ahmed M, Moghe VV, Khan ZY, et al. Prescribing knowledge in the light of undergraduate clinical pharmacology and therapeutics teaching in India: Views of first-year postgraduate students. Adv Med Educ Pract 2012;3:47-53.

(c) 2017 The Authors. Published by Innovare Academic Sciences Pvt Ltd. This is an open access article under the CC BY license (http://creativecommons. org/licenses/by/4. 0/) DOI: http://dx.doi.org/10.22159/ajpcr.2017.v10i12.21930 